\title{
E3 Ubiquitin-Protein Ligase RAD18
}

National Cancer Institute

\section{Source}

National Cancer Institute. E3 Ubiquitin-Protein Ligase RAD18. NCI Thesaurus. Code C106246.

E3 ubiquitin-protein ligase RAD18 (495 aa, $\sim 56 \mathrm{kDa}$ ) is encoded by the human RAD18 gene. This protein plays a role in both ubiquitination and postreplication repair of UVdamaged DNA. 